\title{
FasTDesign Diagram: a new engineering design model based on technical and design functionalities of the innovative product
}

\author{
Odile de Saint Julien, $\mathrm{PhD}$ \\ Strategy, Sustainable Development and Entrepreneurship Department \\ KEDGE Business School Toulon, France \\ Susana Paixão-Barradas, $\mathrm{PhD}$ \\ Strategy, Sustainable Development and Entrepreneurship Department \\ KEDGE Business School Toulon, France
}

\begin{abstract}
The main focused of this FasTDesign Diagram is to fill the lack of engineering design method which integrates simultaneously technique and design activities. This model calls FasTDesign Diagram. Based on the combination of the classic FAST Diagram and the PRD from design, it main role is to determinate the set of the characteristics of the future innovative product that is in perfect harmony with the expectations of the end-user. This FasTDesign Diagram, easy to understand and to implement into the project of innovative product, stimulates the creation of a Techno-Designed Innovation by the sharing of knowledge between engineers and designers. It allows to generate innovation faster, cheaper and with a really value-added for the end - user. This engineering design model, capable of federating heterogeneous actors, is a method for the creation of continuous innovations.
\end{abstract}

Keywords - Innovation, Engineering Design, PDR, FasTDesign Diagram

\section{INTRODUCTION}

In a hyper competitive environment, the intensive development of innovation is a recognized obligation [1]. The engineering design activities have a crucial role in the development of a new innovative product. However, this engineering design is still difficult to understand and to model [2] because these activities are often conducted informally [3].

The literature in engineering design focuses on interdependencies relationships [4] between the different functions of the innovative product [5]. Through various models, like design structure matrices [6] or axiomatic design [7], several authors have highlighted that for a given set of functions, it can exist a different ways to combine these functions. Moreover, technology has a transversal potential that allows to integrate into other disciplines than the engineering sciences [8].

The transversality of the technology promotes a more systemic approach [9] for developing innovation faster, cheaper and which a really value-added for the end-user. Indeed, for some years, the development of innovative products includes a design approach [10] [11].

If the rapprochement between the communities of engineers and designers is now recognized, mainly through the implementation of design process in innovative product development, none of engineering design model integrates simultaneously technique and design activities.

In order to fill this lack, the authors hypothesized that the link of these technique and design activities could be based on the combination of technical functions and functions from the design. How to determine the technical functions and the functions from design? How to combine these different functions to create an innovation including technical functions and functions from design that the authors call Techno-Designed Innovation?

The authors have preferred the FAST Diagram (see Table-1), which is a method of functional analysis to determine all of the technical functions of the future product when the needs of the end-user are clearly identified and defined in terms of functions. Functional analysis fits exactly to the systematic engineering design and the majority of design activities. Concerning the determination of the different function from design, the authors have chosen le Product Requirement Document (see Table-2) which allows to analyze the requirement to provide the different functionalities of the future product based on the real needs of the end-user.

In order to understand how this Techno-Designed Innovation emerges through the combination of technical functions and the functions from design, the authors had to observe this Techno-Designed innovation "in the heat of 
the action". The observation of the development of these Techno-Designed innovations was achieved in sixteen working groups in three workshops teaching innovation (see Table-4). Each working group was constituted by business engineer and designer students. The goal of each workshop was to create one Techno-Designed innovation using the classic FAST Diagram and the PRD. The topic of this Techno-Designed innovation has been given by the authors. It was the same for the sixteen working groups of these three workshops. The results achieved by this research-action, allowed authors to create a new model of engineering innovation.

This article proposes this new engineering design model called the FasTDesign Diagram (see Table-5) that combines technology and design through the different functions of the future product. The Outcome of this engineering design method is a new product including technical functions and functions from design. This outcome is called Techno-Designed Innovation.

\section{The FAST Diagram AND the Product ReQuiREMENT Document (PRD)}

\section{A. The FAST Diagram is a lean best practices to define technical functions}

The FAST Diagram (Functional Analysis System Technique) is a creative thinking [12] process that focuses on the determination of the technical functions of a product and the technical solutions connected with these different functions [13]. The FAST Diagram is a graphical representation of the set of product functions [14]. The classic FAST Diagram has three types of functions that each play a specific role in the determination of the technical functions of a product [15]. The outcome is called Lower Order Function and is the Technical Solution of the FAST Diagram. All of the different functions of the classic FAST Diagram are presented and defined in Table -1 below.

Table -1: All of different functions of the classic FAST Diagram

\begin{tabular}{|l|l|}
\hline $\begin{array}{l}\text { Type of } \\
\text { Functions }\end{array}$ & Traditional Role of the function \\
\hline $\begin{array}{l}\text { Higher Order } \\
\text { Function }\end{array}$ & $\begin{array}{l}\text { Higher Order Function is the main Technical Function of the product. It justifies the existence of the } \\
\text { product to achieve. In order to achieve a product able to answer this demand or this need, the engineer } \\
\text { determines, based on this Higher Order Function, a set of functionalities that has for goal the } \\
\text { realization of this main function. }\end{array}$ \\
\hline Basic Function & $\begin{array}{l}\text { The Basic Function describes the basis technical characteristics of the product and specifically } \\
\text { technical functionalities that are essential to the proper functioning of the product. In the construction } \\
\text { of the classic FAST Diagram, the definition of a Basic Function is important because it will determine } \\
\text { the choice of the set of Secondary Functions. }\end{array}$ \\
\hline $\begin{array}{l}\text { Secondary } \\
\text { Function }\end{array}$ & $\begin{array}{l}\text { The Secondary Functions describe the set of the "advanced" functionalities of the product. Without } \\
\text { these Secondary Functions the Basic Function will not be performed. }\end{array}$ \\
\hline $\begin{array}{l}\text { Lower Order } \\
\text { Function }\end{array}$ & $\begin{array}{l}\text { Lower Order Function represents the Technical Solutions that could be found through these different } \\
\text { functions of the three levels. }\end{array}$ \\
\hline
\end{tabular}

\section{B. The PRD to define the product requirements - Functional, Ergonomic and Formal aspects of the product}

The Product Requirements Document (PRD) is a document, that contains all the requirements to developed a new product and what capabilities the product will possess [16]. Most frequently written for software products, the PRD is written to allow people to understand what a product should do and avoid anticipating or defining how the product will do it in order to later allow interface designers and engineers to use their expertise to provide the optimal solution to the requirements.

The theory, the hierarchy of systems and the visual representation of the PRD, comes from the Concurrent Design Model (CDM). This model, developed in 2003 by Bernabé Hernandis [17], is a useful tool to think and develop all aspects of a product, focusing in three fundamental kind of objectives: Functional Objectives FuO, Ergonomic Objectives ErO and Formal Objectives FoO [18].

To create the PRD, according Mintzberg [19], the designer start to analyze the requirements to provide the functionality of the product, defining the aspects related to technology, machinery, cost, materials, etc.; after, the issues related to Ergonomics, are effectively the Formal and Functional to the user and the designer will discuss relations between the user and the product; at the end, the Formal aspects related to meet aesthetic requirements of product designer to address issues such as semiotics, shape, colors, textures, etc. - see the table below. 
Table -2 PRD: Functional, Ergonomic and Formal aspects of the product

\begin{tabular}{|l|l|}
\hline Type of "Functions" & Traditional Role of the "function" \\
\hline Functional FuO & Technology, Machinery, Materials, Cost, ... \\
\hline Ergonomic ErO & Anthropometry, Comfort, Security, ... \\
\hline Formal FoO & Shape, Form, Color, Texture, Dimension, Geometry, ... \\
\hline
\end{tabular}

\section{FROM THEORIES TO PRACTICES: EMERGENCE OF INNOVATION TECHNO-DESIGNED}

As the authors said in the introduction, the link between technique and design activities to generate innovation faster, cheaper and which a really value-added for the end-user is based on the different functionalities of the future product.

In this context, the function is define as a promise that the designer undertakes to keep towards the actors or the material and natural environments that will interact with this object [20]. Based on the fact that the study of the functions of an object to design depends on knowledge known and used by designers [21], the authors created three workshops teaching innovation. The sixteen working groups which have participated at these workshops were composed of engineers and designers students. The authors have given a unique case study to sixteen groups. This case study which has been given to these working groups for the realization of these Techno-Designed innovations was written from a real problem. The goal was to place participants in a work similar to a business situation. Each group played the game and this has enabled to observe the work of each project team.

Table -3: Case study

\section{The case: Cups and Mugs Design Conception}

You are working in R\&D at Cups and Mugs Design Conception. The Director of the Department of Innovation explains the following situation: coffee is a "social act" in a business meeting. Some important decisions are taken there. Decision can take a long time, very long time... When taking the floor for a presentation, or when you present your arguments... And in the meantime your coffee is getting cold. In other words, the cold coffee just spoil the ending of the meeting and can leave an impression of "coldness". The final moments of a meeting should be as pleasant as the beginning. In this situation, the Director of the Innovation Department asks you to create a Cup to keep the coffee hot as long as possible.

The authors have asked the use of two « tools »: the FAST Diagram (see Table-1), known to engineer students, determines the technical functions of the product, and the Product Requirement Document (see Table-2), known to designer students, determines the functions from the design.

From these classic FAST Diagram and Product Requirement Document, the authors requested the participants to create a new innovative product including technical functions and functions from the design.

The Table-4 is the synthesis of the results of the work of these sixteen groups that have created these TechnoDesigned Innovations.

Table -4 Summary of results from the combination of the classic FAST Diagram and du PRD

\begin{tabular}{|l|l|l|l|l|l|}
\hline $\begin{array}{l}\text { Working } \\
\text { Group }\end{array}$ & $\begin{array}{l}\text { Higher Order } \\
\text { Function }\end{array}$ & Basic function & $\begin{array}{l}\text { Secondary } \\
\text { Technical } \\
\text { Function }\end{array}$ & $\begin{array}{l}\text { Secondary Design } \\
\text { Function }\end{array}$ & Innovation Techno-Designed \\
\hline WG 1 & $\begin{array}{l}\text { Immerse } \\
\text { temperature sensor }\end{array}$ & $\begin{array}{l}\text { Integrate } \\
\text { insulation } \\
\text { material }\end{array}$ & $\begin{array}{l}\text { Immerse retractable } \\
\text { temperature sensor }\end{array}$ & $\begin{array}{l}\text { Adapt Size of the } \\
\text { temperature sensor }\end{array}$ & $\begin{array}{l}\text { Telescopic temperature sensor rod } \\
\text { with size adapted to different } \\
\text { containers (25cl, 50cl...) }\end{array}$ \\
\hline WG 2 & $\begin{array}{l}\text { Release heat in the } \\
\text { container }\end{array}$ & $\begin{array}{l}\text { Integrate heating } \\
\text { conductor }\end{array}$ & $\begin{array}{l}\text { Make rod } \\
\text { watertight }\end{array}$ & $\begin{array}{l}\text { Manufacture rod with } \\
\text { dietary materials }\end{array}$ & $\begin{array}{l}\text { Rod in stainless steel and } \\
\text { watertight made with food } \\
\text { materials }\end{array}$ \\
\hline WG 3 & $\begin{array}{l}\text { retain heat of the } \\
\text { coffee }\end{array}$ & $\begin{array}{l}\text { integrate thermic } \\
\text { fluid }\end{array}$ & $\begin{array}{l}\text { Manufacture } \\
\text { hollow metal rod to } \\
\text { contain the thermic } \\
\text { fluid }\end{array}$ & $\begin{array}{l}\text { Incorporate in this rod } \\
\text { thermic fluid reagent to } \\
\text { heat }\end{array}$ & $\begin{array}{l}\text { metal rod fills with Thermic fluid } \\
\text { which changes color with } \\
\text { temperature of the coffee }\end{array}$ \\
\hline WG 4 & Isolate the container & $\begin{array}{l}\text { Manufacture a } \\
\text { container in }\end{array}$ & $\begin{array}{l}\text { Manufacture a } \\
\text { container in }\end{array}$ & $\begin{array}{l}\text { Re-cover the stainless } \\
\text { steel with silicone }\end{array}$ & $\begin{array}{l}\text { Container in stainless steel re- } \\
\text { covering with silicone material to }\end{array}$ \\
\hline
\end{tabular}




\begin{tabular}{|c|c|c|c|c|c|}
\hline & & silicone & $\begin{array}{l}\text { stainless steel } \\
\text { (inox) }\end{array}$ & (polysiloxane) & protect the hand from the heat \\
\hline WG 5 & $\begin{array}{l}\text { Regulate the } \\
\text { temperature of } \\
\text { coffee }\end{array}$ & $\begin{array}{l}\text { Integrate an } \\
\text { indicator of color }\end{array}$ & $\begin{array}{l}\text { Incorporate } \\
\text { thermostat to } \\
\text { indicate } \\
\text { temperature }\end{array}$ & $\begin{array}{l}\text { Thermic fluid reagent to } \\
\text { heat }\end{array}$ & $\begin{array}{l}\text { Handle of the Cup that changes } \\
\text { color depending on the } \\
\text { temperature of the thermostat }\end{array}$ \\
\hline WG 6 & $\begin{array}{l}\text { Integrate a system } \\
\text { that warms the } \\
\text { coffee }\end{array}$ & $\begin{array}{l}\text { Incorporate a } \\
\text { plug (USB) for } \\
\text { connection to the } \\
\text { computer }\end{array}$ & $\begin{array}{l}\text { Temperature sensor } \\
\text { and electric } \\
\text { resistance }\end{array}$ & $\begin{array}{l}\text { Aspect aesthetic: } \\
\text { incorporate the } \\
\text { secondary technical } \\
\text { function in a saucer }\end{array}$ & $\begin{array}{l}\text { Incorporation in the saucer of the } \\
\text { cup of coffee temperature sensor } \\
\text { and electric resistance which work } \\
\text { with plug (energy source) }\end{array}$ \\
\hline WG 7 & $\begin{array}{l}\text { Manufacture an } \\
\text { solar cup }\end{array}$ & $\begin{array}{l}\text { Integrate an } \\
\text { ecological } \\
\text { energy-giving }\end{array}$ & $\begin{array}{l}\text { Incorporate } \\
\text { photovoltaic cells } \\
\text { on the lid of the } \\
\text { Cup }\end{array}$ & $\begin{array}{l}\text { Incorporate a flexible } \\
\text { cover }\end{array}$ & $\begin{array}{l}\text { Cup with a lid with a flexible } \\
\text { photovoltaic film cover }\end{array}$ \\
\hline WG 8 & $\begin{array}{l}\text { Manufacture an } \\
\text { ecological cup }\end{array}$ & $\begin{array}{l}\text { Integrate an } \\
\text { ecological } \\
\text { energy-giving }\end{array}$ & $\begin{array}{l}\text { Incorporate a } \\
\text { mechanics energy- } \\
\text { giving }\end{array}$ & $\begin{array}{l}\text { Incorporate a crank } \\
\text { handle }\end{array}$ & $\begin{array}{l}\text { Coffee mug with a handle which } \\
\text { is a hand crank to generate power } \\
\text { to keep the coffee hot (dynamo) }\end{array}$ \\
\hline WG 9 & $\begin{array}{l}\text { Maintain the } \\
\text { organoleptic } \\
\text { qualities }\end{array}$ & $\begin{array}{l}\text { Use heat- } \\
\text { resistant } \\
\text { materials }\end{array}$ & $\begin{array}{l}\text { Thermal control } \\
\text { sensor }\end{array}$ & $\begin{array}{l}\text { Ceramic and polythene. } \\
\text { Materials and or resistant } \\
\text { textiles }\end{array}$ & $\begin{array}{l}\text { Coffee cup made in material } \\
\text { resistant to heat. Covered with } \\
\text { insulating textile. Control sensor } \\
\text { integrated in the lid of the Cup }\end{array}$ \\
\hline WG 10 & $\begin{array}{l}\text { Keep the mug } \\
\text { stabilized }\end{array}$ & $\begin{array}{l}\text { Use a system of } \\
\text { weight which } \\
\text { permit the cup to } \\
\text { not spill }\end{array}$ & $\begin{array}{l}\text { Incorporate captor } \\
\text { which detects } \\
\text { changes in } \\
\text { stabilization }\end{array}$ & $\begin{array}{l}\text { Incorporate a } \\
\text { counterweight in the } \\
\text { bottom of the Cup }\end{array}$ & $\begin{array}{l}\text { "In-overturning" coffee cup by } \\
\text { integrating a counterweight in } \\
\text { metal into the lower part of the } \\
\text { Cup }\end{array}$ \\
\hline WG 11 & $\begin{array}{l}\text { Keep good } \\
\text { temperature of the } \\
\text { coffee }\end{array}$ & $\begin{array}{l}\text { Incorporate a } \\
\text { thermostat in the } \\
\text { container }\end{array}$ & $\begin{array}{l}\text { Incorporate } \\
\text { ceramic hob }\end{array}$ & $\begin{array}{l}\text { Integrate "little" and } \\
\text { "nice" ceramic hob }\end{array}$ & $\begin{array}{l}\text { Cup with a saucer consists of little } \\
\text { ceramic hob with a trigger } \\
\text { automatic thermostat }\end{array}$ \\
\hline WG 12 & $\begin{array}{l}\text { Manufacturer a cup } \\
\text { that is easy to carry } \\
\text { and keeps the heat }\end{array}$ & $\begin{array}{l}\text { Manufacturer a } \\
\text { light container }\end{array}$ & $\begin{array}{l}\text { Incorporate lagging } \\
\text { and light materials } \\
\text { like Aluminum }\end{array}$ & Ensure a "good grip" & $\begin{array}{l}\text { Aluminum Coffee Cup. Lid with } \\
\text { "dispenser nozzle" for drinking } \\
\text { and ergonomic handle for easy } \\
\text { transport }\end{array}$ \\
\hline WG 13 & $\begin{array}{l}\text { Adjust the handle of } \\
\text { the Cup }\end{array}$ & $\begin{array}{l}\text { Put or remove } \\
\text { the handle }\end{array}$ & $\begin{array}{l}\text { Predict a notch on } \\
\text { the "body" of the } \\
\text { Cup to set and } \\
\text { remove the handle } \\
\text { by clip }\end{array}$ & $\begin{array}{l}\text { Using carbon or } \\
\text { polypropylene materials } \\
\text { which withstand } \\
\text { pressures clip and unclip } \\
\text { the handle }\end{array}$ & $\begin{array}{l}\text { Removable handle of my coffee } \\
\text { cup =with or without the handle } \\
\text { according to the habits of the user }\end{array}$ \\
\hline WG 14 & Display the heat & $\begin{array}{l}\text { Being able to } \\
\text { sense the heat }\end{array}$ & $\begin{array}{l}\text { Incorporate a } \\
\text { chemical heat gel } \\
\text { in the container }\end{array}$ & $\begin{array}{l}\text { Incorporate a gel which } \\
\text { can change a color with } \\
\text { the temperature of the } \\
\text { coffee }\end{array}$ & $\begin{array}{l}\text { Cup of coffee with the body of } \\
\text { the mug manufactures with heat } \\
\text { which preserves and diffuses the } \\
\text { heat in the hands }\end{array}$ \\
\hline WG 15 & $\begin{array}{l}\text { Keep the coffee } \\
\text { warm }\end{array}$ & $\begin{array}{l}\text { Mix the sugar } \\
\text { and the cream } \\
\text { without opening } \\
\text { the lid }\end{array}$ & $\begin{array}{l}\text { Include a mini } \\
\text { propeller at the } \\
\text { bottom of the } \\
\text { coffee cup }\end{array}$ & $\begin{array}{l}\text { Propeller in } \\
\text { polypropylene }\end{array}$ & $\begin{array}{l}\text { Include a mini propeller at the } \\
\text { bottom of the coffee cup to mix } \\
\text { the sugar and the cream without } \\
\text { opening the lid }\end{array}$ \\
\hline WG 16 & Heat up the coffee & $\begin{array}{l}\text { Heat up the } \\
\text { coffee with a hot } \\
\text { spoon }\end{array}$ & $\begin{array}{l}\text { Using Electrical } \\
\text { resistance }\end{array}$ & $\begin{array}{l}\text { "Dress up" the electrical } \\
\text { resistance with silicone }\end{array}$ & $\begin{array}{l}\text { Hot spoon manufactures in } \\
\text { silicone which heats up the coffee } \\
\text { without will burn your fingers }\end{array}$ \\
\hline
\end{tabular}

Techno-Designed Innovations that are presented in this Table-4 show the diversity of the innovative products that can emerge when two heterogeneous communities work on an innovative product and share their own knowledge. In all these works, endlessly technology interfere with the design. In other words, the technical functions are dependent on the functions observed by designers. And vice-versa. For example, when in working group 1 (WG1), engineer students make this suggestion: 'immerse retractable temperature sensor" immediately, designer students suggest to "adapt the size of this retractable temperature sensor". In WG12, when designer students make this suggestion for the container "ensure a "good grip", designer students suggest to "incorporate lagging and light materials like aluminum", etc.

We can deduce that this Diagram FasTDesign is a model that allows a complementarity of activities between engineers and designers through the functionalities of the object to design. And, the technology and design are not separate in these determinations of the different technical functions and functions from design.

\section{FROM EXPERIMENTS TO THE NEW ENGINEER DESIGN MODEL: THE FASTDESIGN DIAGRAM}

From the work done by sixteen working groups which are summarized in Table 4, the authors have created a new model design engineering that called FasTDesign Diagram in which we find all the technical functions and the functions from design. 
During the realization of these Techno-Designed innovations, we noticed that students do not directly start by completing the FasTDesign Diagram. As the matter of fact, the work begins with a brainstorming session that allows to identify some functionalities of the future Techno-Designed innovation. It is only after a discussion between engineer students and designer students that the realization of the FasTDesign Diagram begins. We have observed the same phenomenon in the sixteen working groups in the three workshops.

This observation allowed us to modify the classic FAST Diagram. The Higher Order Function, which is the main function that starts the construction of the classic FAST, has been replaced by the Set of Technical Functions which includes all of the technical functions and the Set of Design Functions that includes all of the functions from design.

The results achieved by this research-action, allowed authors to create a new engineering design model to generate a continuous innovations. The Table-5 shows it.

Table -5: The FasTDesign Diagram

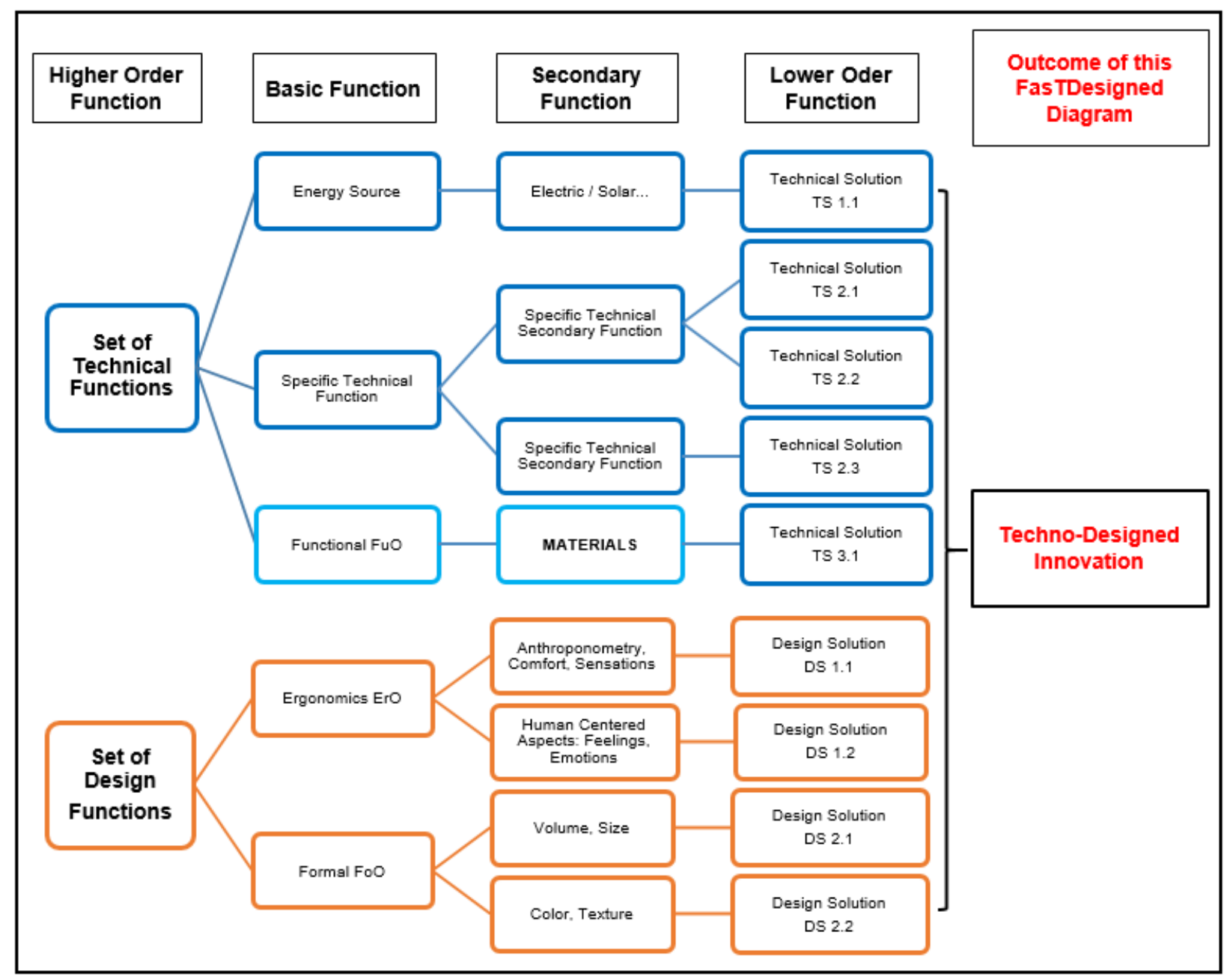

In this Table-5 we can see the functions provides from Design, highlighted in orange: the Ergonomics and the Formal Objectives; and the secondary functions associated, like Comfort, Emotions, Feelings... Volume, Size, Color, Textures...

The determination of the Techno-Designed functions is based on the two basic principles: firstly, the search for balance between technology and design and secondly the "principle of joint optimization" [22] which puts in the same rank technology and design in terms of product functions. The balance between the technical and functions from design highlights the relations of interdependencies between these two categories of functions.

Table 6 includes all the different functions of the FasTDesign Diagram. 


\begin{tabular}{|l|l|l|}
\hline Type of Functions & $\begin{array}{l}\text { Description of the different } \\
\text { functions (from FAST) }\end{array}$ & Description of the different functions (from PRD) \\
\hline Higher Order Function & Set of Technical Functions & Set of Design Functions \\
\hline Basic Function & $\begin{array}{l}\text { Energy Source } \\
\text { Specific Technical Function of } \\
\text { this future Innovation Techno- } \\
\text { Designed }\end{array}$ & $\begin{array}{l}\text { Functional FuO } \\
\text { Ergonomics ErO } \\
\text { Formal FoO }\end{array}$ \\
\hline Secondary Function (SF) & $\begin{array}{l}\text { Electric, solar or another } \\
\text { source of energy } \\
\text { Specific Secondary Function } \\
\text { of this future Innovation } \\
\text { Techno-Designed }\end{array}$ & $\begin{array}{l}\text { From Functional FuO : cost, production, material } \\
\text { details } \\
\text { From Ergonomic ErO : Anthropometry, Comfort and } \\
\text { Sensations AND Human Centered Aspects : Fellings } \\
\text { and Emotions } \\
\text { From Formal FoO: Volume and Size AND Color and } \\
\text { Texture }\end{array}$ \\
\hline Lower Order Function (LOF) & $\begin{array}{l}\text { Technical Solutions including } \\
\text { Solutions from FuO }\end{array}$ & Design Solutions with ErO and FoO \\
\hline
\end{tabular}

Table- 6 shows the types of functions provided from the classic FAST Diagram, design and the role that they assume on the FasTDesign Diagram. Functional Objectives FuO are considerate the Basic Technical Function because they are directly linked to the technical Engineering functions of the product. By the other hand the Ergonomic and the Formal Objectives are the Basic and Secondary functions comes from Design, directly linked to the user perceptions and anatomy. Through this joint development of technical and functions observed from design, the team looking for a joint optimization of the product for the end user.

\section{IV.CONCLUSION}

This exploratory research conducted in three workshops composed of sixteen working groups, had ambition to federate multidisciplinary teams about the design of a Techno-Designed innovation. In order to promote the sharing of knowledge and competencies, the authors have chosen to combine two tools usually used by engineers or designers. This new engineering design model has proved to be a model that promotes the exchange of point of views about the design of innovation. It showed his ability to generate, simultaneously, several technical functions and functions from design. Easy to understand and implement as well by a technical or non-technical professionals, it allows to articulate techniques and design activities. Finally this model can be used to guide the development of continuous innovation and help innovators in design of the Techno-Designed innovation mainly when the new product must be technically efficient and perfectly adapted to the uses and needs of the end-user. This research is exploratory, the results are intermediate. The authors do not allow a generalization of the results. An implementation of this new model design engineering in companies is necessary for external validation of this model.

\section{REFERENCES}

[1] P. Le Masson, B. Weil and A. Hatchuel, "Strategic Management of Innovation and Design”, New-York: Cambridge University Press, 2010

[2] P. Joore and H. Brezet, "A Multilevel Design Model: the mutual relationship between product-service system development and societal change processes, Journal of Clearner Production, vol.97, p.92-105, 2015

[3] A.Hatchuel, P. Le Masson, Y. Reich and B. Weil, "A systematic Approach of design theories using generativeness and robustness", International Conference of Engineering Design, ICED’11, Copenhagen, Technical University of Denmark, 2011

[4] CY. Baldwin and KB. Clark, "Design Rules, Volume 1: The power of modularity", The MIT Press, Cambridge, MA, USA, 2000

[5] D. Braha and Y. Reich, "Topologial structures for modelling engineering design processes", Resaerch in Engineering Design, Vol.14, ${ }^{\circ} 4$, p.185-199, 2003

[6] KT. Ulrich and SD. Eppinger, "Product Design and Development", $4^{\text {th }}$ edition, McGraw Hill, 2008

[7] NP. Suh, "Axiomatic Design: advances and applications", Oxford University Press, 2001

[8] T. Shinn, "New Sources of Radical Innovation: Research technologies transversality and Distributed Learning in a Post-industrial Order", Innovation Science, and Institutional Change, A research Handbook, Edited by J. Hage and M. Meeus, Oxford, University Press, Chapter 14, p.313-333, 2006

[9] G. Pahl and W. Beitz, “Engineering Design: A systemic Approach”, Edited by K. Wallace, Springer, 2th edition, 2013

[10] J. Liedtka and T. Ogilvie, "Designing for growth: a design thinking tool kit for managers", Columbia University Press, New York, 2011

[11] VP. Seidel and SK. Fixson, "Adopting Design Thinking in Novice Multidisciplinary Teams: The Application and Limits of Design Mathodes and Reflexive Practices", Journal of Product Innovation Management, vol.30, p.19-33, 2013

[12] C.W. Bytheway, "Fast Creativity at innovation", J. Ross Publishing-Inc., 2007.

[13] J. Bytheway, "Finding Hidden Functions in FAST Diagrams Using Reserve How", Save International Value World, Vol.35, n², 2012.

[14] J. Borza J., "FAST Diagrams: the foundation for creating effective function models", presented to TrizCom Detroit, 28-29 nov., 2011. 
[15] P. Johnson, "FAST diagramming made easy: Straightforward techniques for your highway project", AASHTO Value Engineering Peer Exchange Workshop Minneapolis, Minnesota, July 9-12, 2013.

[16] Zahid I.N., "Product Management: The Art and Science of Managing Network and Communications Industry Products". Xlibris Corporation, 2013.

[17] Hernandis, B., "Desarrollo de una metodología sistémica para el diseño de productos industriales". Valencia, España: Universidad Politécnica de Valencia, 2003.

[18] Paixão-Barradas, S., Hernandis O., B., Merino, E., "The role of innovation in concurrent design model (CDM)". International Conference on Integration of Design, Engineering and Management for Innovation (iDEMi 09); Porto, Portugal, 2009.

[19] Mintzberg, H., "Managing the Form, Function and Fit of Design”. Ed Design Management Journal, Vol.2, n³, 1991.

[20] A. Hatchuel and B. Weil, "A new approach of innovative design: an introduction to C-K theory". International Conference on Engineering Design, ICED’03, Stockholm, Sweden, 2003

[21] M. Agogué and A. Hatchuel, "Reinventing classics: the hidden design strategies of renowefs chefs", Research in Engineering Design, vol.27,n², p.165-177, 2016.

[22] EL. Trist, "Referent Organizations and the Development of Inter-Organizational Domains", Human Relations, Vol.36, p.269-84, 1983 